\title{
Composition of Cigarette Smoke: Effects of Ammonium Sulfamate in Clgarette Paper*
}

\author{
by Iroing Michelson and Gunter Rathkamp \\ Environmental Health and Safety Research Associates, New Rochelle, New York, USA \\ and
}

Tobacco Analysts and Consultants, White Plains, New York, USA

The use of ammonium sulfamate (AS) in cigarettes to produce a substantial reduction in benzo(a)pyrene in cigarette smoke was reported by Alvord and Cardon (1) in 1956. Because benzo(a)pyrene was then considered the most important of the known carcinogens in cigarette smoke, the report stimulated further studies, with conflicting results: some confirmed the reduction $(2,3)$, some found no reduction $(4,5,6)$, and some found increases rather than reductions $(6,7)$. Thereafter, interest in the use of AS waned. Recent biological tests, however, have demonstrated that AS in cigarette paper reduces the carcinogenic activity of cigarette smoke on mouse skin (8). Chemical tests have also revealed differences in concentrations of several constituents in smoke of AS-treated cigarettes, though not in benzo(a)pyrene. We present here the differences which we have found so far.

\section{MATERIALS AND METHODS}

The tests were performed on treated and untreated cigarettes which differed only in that the treated cigarettes had had AS applied to the paper. The AS was first incorporated into a commercial cigarette paper by running part of a $500 \mathrm{lb}$. roll through a solution of AS in water (about $15 \%$ by weight), then through squeeze rolls, and finally over heated drying cylinders. The treated paper contained approximately $0.3 \mathrm{mg} \mathrm{AS} / \mathrm{cm}^{2}$. The remainder of the roll was used to make the untreated control cigarettes.

King size $(85 \mathrm{~mm})$ non-filter cigarettes were made in a commercial cigarette making machine, using conventional American-blend tobacco. The treated cigarettes contained approximately $7 \mathrm{mg}$ AS/cigarette. Smoking was done by the standard method of the U.S. Federal Trade Commission: puff volume $35 \mathrm{ml}$, puff duration 2 sec., puff frequency $1 / \mathrm{min}$., butt length $23 \mathrm{~mm}$; tar** and nicotine were determined by the procedures specified in this method (9). Comparative tests were performed only between treated and untreated cigarettes made from the same batch of tobacco and the same roll of paper.

\footnotetext{
- Reseived for publication: 10th July, 1973.

* The term "tar" is used throughout for convenience. It is adnawledged that it is not bemically aecurate in the strictest sense.
}

The static burning rates of the cigarettes were determined by the method of Hoffmann and Wynder (10), and the $\mathrm{pH}$ of the whole smoke by the method of Sensabough and Cundiff (11). The polycyclic hydrocarbons were determined by the methods of $W$ ynder and Hoffmann (7), with some modifications by Guerin (12) and Rathkamp and Hoffmann (13). The nitrosamines were determined by the method of Hoffmann and Vais (14), and the indoles by the method of Hoffmann and Rubin (15).

Gas phase components were determined by the following methods: acetaldehyde and acrolein, by the method of Laurene et al. (x6); formaldehyde and $\mathrm{NO}_{x}$, by the methods of Newsome et al. (17); HCN, by the method of Collins et al. (x8); and $\mathrm{CO}$ and $\mathrm{CO}_{2}$, by the method of Newsome and Keith (19). These methods were modified to some extent by Guerin (12).

The comparison of the taste of treated and untreated cigarettes was performed by triangular taste tests, in accordance with the procedures of Roessler et al. (20). The panel members were each presented with three unidentified cigarettes, two of which were alike and one was different (either two treated and one untreated, or two untreated and one treated), and asked to identify which one tasted different from the others.

The quantitative data presented below are either in the form of yield/cigarette when smoked to equal butt length, or in the form of concentration per equal volume or equal weight of effluent. These concentrations per equal volume or equal weight correspond to yields per cigarette when the treated cigarettes are smoked to an equal number of puffs/cigarette, or an equal tar yield/cigarette, as the control cigarettes. In some cases, the data are presented in both forms.

\section{RESULTS AND DISCUSSION}

\section{Tar and Nicotine}

Since AS is a fire retardant, the treated cigarettes burned at a slower rate than the untreated controls. As a result, more puffs were obtained from the treated cigarettes, when both were smoked to the same standard butt length. The tar and nicotine yields were likewise also increased. The $\mathrm{pH}$ of the smoke, 
Table 1. Smoking characteristics of untreated and treated cigarettes when smoked to $23 \mathrm{~mm}$ butt.

\begin{tabular}{lccc} 
& Untreated & Treated & Change \\
\hline Static burning rate, $\mathrm{mg} / \mathrm{min}$. & 74 & 56 & $-24 \%$ \\
Puffs/cigarette & 8.7 & 9.8 & $+12 \%$ \\
Tar, mg/cigarette & 20.7 & 26.0 & $+26 \%$ \\
Nicotine, mg/cigarette & 0.85 & 1.10 & $+29 \%$ \\
pH of smoke, puff $\neq 3$ & 6.08 & 6.06 & - \\
pH of smoke, puff $\neq 9$ & 5.85 & 5.90 & - \\
\hline
\end{tabular}

however, was not affected by the AS treatment. Table $I$ presents the average yields of tar and nicotine and puffs found in tests by three laboratories.

Since increased yields of tar and nicotine may be objectionable, the yields of treated cigarettes can be reduced to those of untreated cigarettes, e. g., by limiting the number of puffs that can be drawn, by reducing the diameter or length of tobacco rod smoked. Such a limitation is achieved in some commercial cigarettes by replacing part of the tobacco rod by filter tips of morethan-average length. This technique would be particularly suitable for AS-treated cigarettes, in part to prevent the increase of yields of tar and nicotine, and also to take advantage of the possible saving in the tobacco cost, with no reduction in delivery of taste elements to the smoker.

\section{Polycyclic Hydrocarbons}

Three polycyclic hydrocarbons considered important for characterizing the chemical nature of cigarette smoke were assayed: the benzo(a)pyrene, benzo(a)anthracene, and phenanthrene were found to be virtually unchanged in concentration. But the profile analyses (13) of the fractions containing these hydrocarbons revealed changes in concentrations of associated hydrocarbons (Table 2).

The hydrocarbons listed in Table 2 were determined quantitatively by means of internal standards $\left({ }^{14} \mathrm{C}\right.$ labelled traces of these hydrocarbons added prior to isolation of the fractions). In addition to those listed, many other smoke components were observed on the gas chromatograms, but were not assayed quantitatively because internal standards for these had not been added. Nevertheless, the chromatograms indicated considerable
Table 2. Concentrations of polycycllc hydrocarbons in the smoke of untreated and treated clgarettes.

\begin{tabular}{lcc|c}
\hline Polycyclic hydrocarbon & Untreated & Treated & Change \\
\hline Benzo(a)pyrene & $1.12 \mathrm{ppm}$ & $1.05 \mathrm{ppm}$ & $-6 \%$ \\
Benzo(a)anthracene & 1.68 & 1.57 & $-7 \%$ \\
Phenanthrene & 21.0 & 21.2 & $+1 \%$ \\
Chrysene* $^{*}$ & 2.2 & 1.9 & $-14 \%$ \\
Fluorene* & 16.9 & 12.1 & $-28 \%$ \\
\hline
\end{tabular}

- from benzo(a)anthracene profile

"* from phenanthrene profile

changes in the smoke of treated cigarettes, most notably in the benzo(a)pyrene fraction, in which there were extensive changes (Figure 1), in two analyses of each. Two of the benzo(a)pyrene fraction components which appear to have been reduced by over $50 \%$ have been tentatively identified by mass spectrometry: benzofluoranthenes ( $80 \%$ pure), at $74 \mathrm{~min}$., and perylene, at $92 \mathrm{~min}$.

A series of other as-yet unidentified components in this profile, which appear in the chromatogram of the control cigarette in the interval between 48 and 64 min., and at $38,43,79$, and $99 \mathrm{~min}$., have also been largely eliminated by the AS treatment. In contrast only a few new peaks, also unidentified, have been introduced.

\section{Nitrogenous Compounds}

Two kinds of nitrogenous compounds were determined in the smoke of these cigarettes: nitrosamines and indoles. These components were of interest because nitrosamines exhibit carcinogenic activity, and 3methylindole (skatole) has been recently reported to cause pathological damage in pulmonary tissues (21), and because the high nitrogen content of AS caused us to suspect that the nitrosamines and indoles might thereby be increased in the smoke of AS-treated cigarettes.

Total delivery of these compounds, when the cigarettes were smoked to equal butt length, showed only small changes. But when compared on a concentration basis, these components were found to have been moderately reduced in the smoke of the treated cigarettes (Table 3).

Table 3. Nitrosamines and Indoles from untreated and treated cigarettes.

\begin{tabular}{|c|c|c|c|c|c|c|}
\hline \multirow[b]{2}{*}{ Component } & \multicolumn{3}{|c|}{ Yields/cigarette smoked to $23 \mathrm{~mm}$ butt } & \multicolumn{3}{|c|}{ Yields/cigarette smoked to equal tar deliveries } \\
\hline & Untreated & Treated & Change & Untreated & Treated & $\begin{array}{l}\text { Change in } \\
\text { Concentration }\end{array}$ \\
\hline & \multicolumn{2}{|c|}{ (ng/cig.) } & & \multicolumn{2}{|c|}{ (ng/cig.) } & \\
\hline Dimethylnitrosamine & 118 & 108 & $-8 \%$ & 118 & 86 & $-27 \%$ \\
\hline \multirow[t]{2}{*}{ Methylethylnitrosamine } & 47 & 42 & $-11 \%$ & 47 & 33 & $-30 \%$ \\
\hline & \multicolumn{2}{|c|}{ ( $\mu \mathrm{g} / \mathrm{cig})}$. & & \multicolumn{2}{|c|}{$(\mu g /$ cig. $)$} & \\
\hline Indole & 11.1 & 12.3 & $+11 \%$ & 11.1 & 9.8 & $-11 \%$ \\
\hline 3-Methylindole & 11.8 & 12.2 & $+3 \%$ & 11.8 & 9.7 & $-18 \%$ \\
\hline
\end{tabular}


Figure 1. Gas chromatograms of the benzo(a)pyrene fractions of ammonium-sulfamate-treated clgarettes and untreated controls.

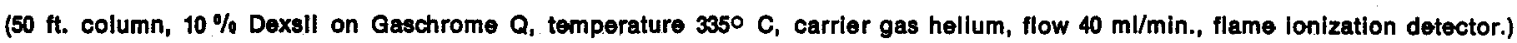
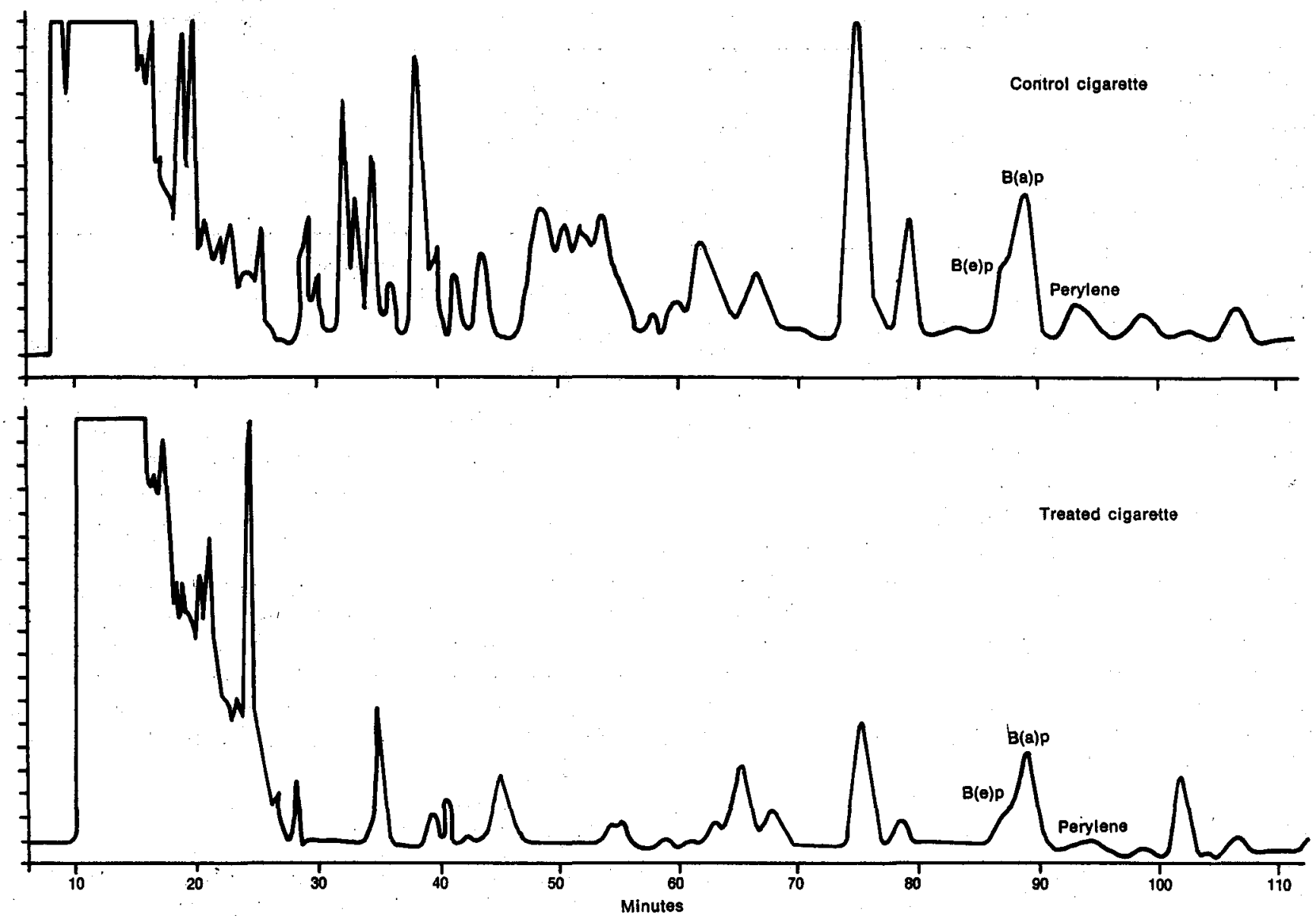

\section{Gas Phase Components}

Seven constituents of the gas phase were determined. When smoked to standard butt length, the treated cigarettes generated about 10\% less of three components (i. e. acetaldehyde, acrolein, and formaldehyde) despite the $12 \%$ increase in puffs per cigarette. When only equal numbers of puffs are drawn from both kinds of cigarettes, the smoke of the treated cigarettes had about 20\% lower yields (or concentrations) than that of the controls (Table 4).
On the other hand, three components (i. e. carbon dioxide, hydrogen cyanide, and nitrogen oxides) were found to be virtually unchanged in concentration, and one, carbon monoxide, was increased $29 \%$. The problem of the carbon monoxide is discussed elsewhere (8).

Taste

Since its effect on the taste of the smoke is an important consideration in the practicality of a cigar-

Table 4. Cas phase components from untreated and treated clgarettes.

\begin{tabular}{|c|c|c|c|c|c|c|}
\hline \multirow[b]{2}{*}{ Component } & \multicolumn{3}{|c|}{ Yields/cigarette smoked to $23 \mathrm{~mm}$ butt } & \multicolumn{3}{|c|}{ Yields/cigarette smoked to equal number of puffs } \\
\hline & Untreated & Treated & Change & Untreated & Treated & $\begin{array}{c}\text { Change in } \\
\text { Concentration }\end{array}$ \\
\hline & \multicolumn{2}{|c|}{ (mg/cig.) } & \multicolumn{4}{|c|}{ (mg/cig.) } \\
\hline Acetaldehyde & 1.00 & 0.94 & $-6 \%$ & 1.00 & 0.84 & $-16 \%$ \\
\hline Acrolein & 0.098 & 0.085 & $-13 \%$ & 0.098 & 0.076 & $-23 \%$ \\
\hline Formaldehyde & 0.030 & 0.026 & $-13 \%$ & 0.030 & 0.023 & $-23 \%$ \\
\hline Hydrogen cyanide & 0.203 & 0.223 & $+10 \%$ & 0.203 & 0.199 & $-2 \%$ \\
\hline \multirow[t]{2}{*}{ Nitrogen oxides } & 0.380 & 0.425 & $+12 \%$ & 0.380 & 0.380 & - \\
\hline & & & \multicolumn{4}{|c|}{ (vol. $\%)$} \\
\hline Carbon dioxide & & & & 9.4 & 9.4 & - \\
\hline Carbon monoxide & & & . & 4.70 & 6.08 & $+29 \%$ \\
\hline
\end{tabular}


Table 5. Trlangular taste tests (treated versus untreated clgarettes).

\begin{tabular}{c|c|c|c}
\hline $\begin{array}{c}\text { Session } \\
\neq\end{array}$ & Type of cigarette & $\begin{array}{c}\text { No. of } \\
\text { smokers }\end{array}$ & $\begin{array}{c}\text { No. of correct } \\
\text { identifications }\end{array}$ \\
\hline 1 Commercial, filter & 17 & 6 \\
2 Commercial, non-filter & 18 & 3 \\
$3 \quad$ Commercial, non-filter & 18 & 7 \\
4 Custom, non-filter & 18 & 7 \\
5 & Custom, non-filter & 18 & 7 \\
Average & 18 & 6 \\
\hline
\end{tabular}

Conclusion: no detectable difference in taste of smoke.

ette additive, the effect of the AS treatment was explored by triangular taste tests. The taste panels were made up of $17-18$ smokers; five smoking sessions were held, using two of the most popular commercial cigarettes (filter and non-filter) at three sessions and custom-made samples at the others. (The AS was applied to the commercial cigarettes manually, by means of a cellulose sponge.)

Approximately six correct identifications of the odd cigarette could be expected at each session by chance alone, if no difference in taste were detectable. A significantly larger number would be possible only if a detectable difference actually existed: with 1o correct identifications, a statistically significant difference is barely reached (20). As shown in Table 5, the panels averaged 6 . correct designations, showing that the panels were unable to distinguish the treated cigarettes from the untreated controls (22).

\section{SUMMARY AND CONCLUSIONS}

Treatment of cigarette paper with ammonium sulfamate was found to cause changes in the composition of cigarette smoke, in the concentrations of components of both the gas and particulate phases. The concentrations of several polycyclic hydrocarbons were reduced by over $25 \%$, though benzo(a)pyrene was virtually unchanged. The concentrations of two nitrosamines were also reduced more than $25 \%$, while indole and skatole concentrations were reduced about $15 \%$. Among the gas phase components, acetaldehyde, acrolein and formaldehyde were reduced about $20 \%$; only carbon monoxide was moderately increased.

Since these tests explored only small segments of the spectrum of cigarette smoke components, it is not known which of the observed reductions, if any, contributed to the reduction of biological activity of the smoke of treated cigarettes reported by Bock et al. (8). The tests indicate only that the nature of the smoke has been modified in several respects.

The tar and nicotine yield of the treated cigarette was higher than that of the control cigarette, but this can be compensated for by reducing the diameter or length of tobacco rod available to be smoked.
ZUSAMMENFASSUNG

UND SCHLUSSFOLGERUNGEN

Es wurde beobachtet, daß die Behandlung von Cigarettenpapier mit Ammoniumsulfamat Veränderungen in der Zusammensetzung des Cigarettenrauches, $d . h$. in den Konzentrationen von Inhaltsstoffen der Gas- und der Partikelphase, bewirkt. Die Konzentrationen mehrerer polycyclischer Kohlenwasserstoffe wurden um mehr als $25 \%$ vermindert, wohingegen der Gehalt an Benz(a)pyren unverändert blieb. Die Konzentrationen zweier Nitrosamine wurden gleichfalls um mehr als $25 \%$ reduziert, während Indol und Skatol um etwa $15 \%$ verringert wurden. In der Gasphase gingen die Gehalte an Acetaldehyd, Acrolein und Formaldehyd um etwa 20\% zuriuck; nur der Gehalt an Kohlenmonoxid stieg schwach an.

Da die Analysen nur kleine Teile des Spektrums der $\mathrm{Zu}-$ sammensetzung des Cigarettenrauches erfaßten, geben sie keinen Aufschluß darüber, welche der beobachteten Reduzierungen, wenn überhaupt, zu der Verminderung der biologischen Aktivität des Rauches Ammoniumsulfamat-behandelter Cigaretten beigetragen haben könnte, über die Bock et al. berichteten (8). Die Untersuchungen zeigen lediglich, daß die Beschaffenheit des Rauches in mehrfacher Hinsicht verändert wird.

Die Ausbeute an Kondensat und Nikotin war bei Ammoniumsulfamat-behandelten Cigaretten größer als bei den Vergleidiscigaretten; dies kann aber dadurch ausgeglichen werden, daß der Durchmesser oder die Länge des zu verrauchenden Tabakstranges vermindert werden.

\section{RESUME ET CONCLUSIONS}

On a observé que le traitement du papier de cigarette par du sulfamate d'ammonium provoque un dhangement de la composition de la fumée, tant dans la phase gazeuse que particulaire. Les concentrations de plusieurs hydrocarbures polycycliques ont été réduites de plus de $25 \%$, malgré que la teneưr en benzo(a)pyrène reste inchangée. La concentration de 2 nitrosamines est réduite également de plus de $25 \%$, les concentrations $d$ 'indole et de scatole environ de $15 \%$. Dans la phase gazeuse, on observe une diminution d'environ $20 \%$ des concentrations en acétaldéhyde, acroléine et formaldéhyde, tandis que seule la teneur en monoxyde de carbone augmente faiblement.

Ces tests ne concernant que de petites parties du spectre des composants de la fumée de cigarette, on ne peut en déduire quelles réductions observées provoquent la diminution de l'activité biologique de la fumée décrite par Bock et al. (8) dans les cigarettes traitées. Les tests démontrent seulement que la nature de la fumée est modifiée.

Le rendement en condensats et nicotine des cigarettes traitées est plus élevé que celui de la cigarette témoin, mais on peut compenser ceci en diminuant le diamètre ou la longueur du boudin de tabac. 


\section{REFERENCES}

1. Alvord, E. T., and S. Z. Cardon: The inhibition of formation of 3,4-benzpyrene in cigarette smoke; Brit. J. Cancer 20 (1956) 498-503.

2. Lindsey, A. J., K. Persaud and A. Candeli: Reduction of benzpyrene in tobacco smoke; Brit. Med. J. 1959 (2), 821.

3. Candeli, A., A. J. Lindsey and K. Persaud: Carta di sigarette al sulfammato di ammonio e idrocarburi cancerigeni; Boll. Soc. Ital. Biol. Sper. 36 (1960) 452-454.

4. Bentley, R. H., and J. G. Burgan: Polynuclear hydrocarbons in tobacco and tobacco smoke, Part III: The inhibition of the formation of 3,4-benzpyrene in cigarette smoke; Analyst 85 (1960) $727-730$.

5. Cuzin, J. L., M. Hubert-Habart, R. Royer and R. Latarjet: La production du benzo-3,4-pyrène dans des cigarettes à papier imprégné de sulfamate d'ammonium; Bull. Soc. Chim. Fr. 1960, 982.

6. Pyriki, C., W. Moldenhauer and T. Knappe: Zur Frage der Behandlung des Zigarettenpapiers und des Tabaks zwecks Verminderung von polycyclischen Kohlenwasserstoffen in deren Rauch; Ber. Inst. für Tabakforschung 12 (1965) 37-55.

7. Wynder, E. L., and D. Hoffmann: Tobacco and tobacco smoke, Studies in experimental carcinogenesis; Academic Press, New York, 1967.

8. Bock, F. G., I. Michelson, I. D. J. Bross and R. L. Priore: Carcinogenic activity of smoke condensates from cigarettes with ammonium sulfamate in the paper; Cancer 33 (1974) 1010-1016.

9. Pillsbury, H. C., C. C. Bright, K. J. O'Connor and F. W. Irish: Tar and nicotine in cigarette smoke; J. Assoc. Offic. Agr. Chemists 52 (1969) 458-462.

10. Hoffmann, D., and E. L. Wynder: Cancer Res. 27 ( 1967$) 172$.

xx. Sensabaugh, A. J., and R. H. Cundiff: Tob. Sci. $1 x$ (1967) 25.

12. Guerin, M. R.: Compilation of analytical procedures (Tobacco Smoke Analyses Project); Oak Ridge National Laboratory, in preparation.
13. Rathkamp, G., and D. Hoffmann: Polynuclear aromatic hydrocarbon profile of tobacco smoke; Inform. Bull. CORESTA, 1972-Special, 14 .

14. Hoffmann, D., and J. Vais: Analysis of volatile $\mathrm{N}$-nitrosamines in unaged smoke of cigarettes; 25th Tobacco Chemists' Research Conference, Louisville, Ky., I97x.

15. Hoffmann, D., and J. Rubin: Quantitative determination of indoles in tobacco smoke; Beitr. Tabakforsch. 3 (1966) $409-414$.

16. Laurene, A. H., L. A. Lyerly and G. W. Young: Tobacco 159 (1964) 34-37.

17. Newsome, J. R., V. Norman and C. H. Keith: Tob. Sci. 9 (1965) 102-105.

18. Collins, P. F., N. W. Sarji and J. F. Williams: Tob. Sci. 14 (1970) $12-15$.

1.9. Newsome, J. R., and C. H. Keith: Tob. Sci. 9 (1965) 65-69.

20. Roessler, E. B., J. Warren and J. F. Guymon: Significance in triangular taste tests; Food Research 13 (1948) 503-505.

21. Carlson, J. R., M. T. Yokoyama and E. O. Dickinson: Induction of pulmonary edema and emphysema in cattle and goats with 3-methyl indole; Science 176 (1972) 298-299.

22. Morgareidge, K.: Private communications (Food and Drug Research Laboratories).

\section{Acknowledgement}

The authors are indebted to Oak Ridge National Laboratory, Oak Ridge, Tenn., and to Fitelson Laboratories, New York, N. Y., for performing many of the chemical tests, and to Food and Drug Research Laboratories for performing the taste tests.

The authors' address:

Environmental Health and Safety Research Associates, 155 Calhoun Avenue, New Rochelle, New York, 1080x, USA. 